\title{
Evolution of New Woman: A New Façade of Indian Culture in the Select Novels of Manju Kapur and Shobha De
}

\author{
Priyanka Mahajan
}

\begin{abstract}
The present paper is a sincere and humble effort to explore the evolution of new woman in India after the partition. The birth of "new woman" in India is a reality, as the concept and position of womanhood has changed in the modern context. Attitudinal shift can be seen in the woman who longer shies away from taking initiatives. Though this new change in thought has its variables, the results are relative depending upon the individual. Through present paper, the researcher has attempted to investigate a new façade of Indian culture that gave birth to a new woman presented in the select novels of Manju Kapur and Shobha Dee. The new image of women presented by novelists under study is ambitious, lustful, power hungry and bold. She is an assimilation of western influences as well as her native culture. She is a hybrid who despite of all kinds of upheavals, is able to strike a balance among diverse spheres of her life. All domains of her growth, social, political and psychological remain the focus of our investigation.
\end{abstract}

Index Terms - Evolution, façade, new woman, psychological.

\section{INTRODUCTION}

This research paper is a sober attempt to study the evolution of new woman in India after the partition. It is pertinent to note that throughout the history of mankind, from its Paleolithic civilization, goddess worship was widely prevalent, and families were matriarchal in their structure. But in the course of time civilization was overtaken by patriarchal dominance, and worship of the male deity became the dominant concept. In social set up, male ego acquired control and predominance in all spheres of social activities such as ritualistic performances, politics, religion and ethnic which in turn submitted women to the place of utter subordination, a secondary place; the insignificant.

The phrase 'new woman' [1] was coined originally by Henry James and intended by him to characterize American expatriates living in Europe. Women of affluence and sensitivity exhibited an independent spirit and were accustomed to acting on their own. The socio-political and economic forces brought about awareness in women who took up the new roles in the social, political and economic life.

In the post World War, the slang 'Flapper' was applied to a 'new breed' of young western women who revolted against the Victorian conventional set up and assumed new fashionable and modern roles in the society as quoted by

Manuscript received October 17, 2013; revised January 18, 2014.

Priyanka Mahajan is with the Punjab Technical University, Jalandhar, India (e-mail: priyankamahajan.info@gmail.com).
Rosenberg "She wore short skirts, spent time and money on their bobbed hair, listened to jazz, and flaunted their disdain for what was then considered ... [2].

\section{A. Status of Women in India: I Historical Perspective}

In India, the situation was entirely different from the West. Indian woman was subjugated since ages. She was under the authority of man. Medieval India was not women's age and it was supposed to be the 'dark age' for them. The Hindu moral code known as "The Laws of Manu" denies woman an existence apart from that of her husband. Since the publication of Bankim Chander Chatterjee's Rajmohan's Wife in 1864, a significant number of authors have portrayed Indian women as long-suffering wives and mothers silenced by patriarchy:

When looking at these narratives, one can say that silence and tolerance were the main tools with women to live under patriarchal hegemony. In Indian patriarchal society, a husband was considered God, however, cruel and indifferent he may be. She had been taught since her childhood that she has to obey her husband and family. Her parents offered her no chance to think about her identity. Different factors were responsible for woman subjugation. They can be categorized as social, cultural, traditional, and so on. Culture and society had imposed many kinds of norms on her and she was supposed to follow them religiously, she did not have the right to cross the "Laxaman Rekha".

Many foreign conquests resulted in the decline in women's status. The Muslim invaders brought with them their own culture. For them, woman was the sole property of her father, brother or husband and she did not have any will of her own This type of thinking also crept into the minds of Indian people and they also began to treat their own women like this. The Indians wanted to shield their women folk from the barbarous Muslim invaders. Polygamy was a norm for these invaders and they picked up any women they wanted and kept her in their "harems". So, in order to protect themselves, Indian women started using 'Purdah', (a veil), which covers body. Due to this reason their freedom was lost. They were not allowed to move freely and this led to the further deterioration of their status. These problems related with women resulted in changed mindset of people. Now they began to consider a girl as misery and a burden, which has to be protected from the eyes of intruders and needs extra care. Sexism is the major factor responsible for female subjugation in the society. In Indian society the birth of a girl child is not welcomed. Sexual abuse and flesh trade are growing evils which threaten the existence of women. 


\section{B. Start of Wave of Feminism in India with Post-Colonial Novelists}

In the post-colonial era, the portrayal of women in Indian novel in English underwent a radical change. The conventional ideal woman who meekly tolerated traditional, domestic and sexual oppression and whose mouth was muzzled, voice arrested and movements fettered by patriarchal norms and control, was replaced by the "new woman" who started resisting traditions, orthodox concepts and values. Western feminism sought to change human consciousness about male dominance.

Raja Rao in his novel Kanthapura (1938) presented an old woman as the chief protagonist who gives vivid details about casteism, religion, British rule, illiteracy, landlords, moneylenders, child marriages. There is a Brahmin quarter, a weaver quarter, a Sudra quarter, a pariah quarter for the untouchables.

\section{Impact of Freudian Theories of Psychoanalysis on Post -Colonial Writers}

The conspicuous feature of the Indian fiction written after the post-world war is the deflation of self. The psycho-analytical theories of self, devaluation of self, neurosis, sexual repression and nausea given by Dr Karen Horney in Neurosis and Human Growth (1950) and Freud in Life and Work of Sigmund Freud (1953-1957), published in three volumes, impacted greatly on the post-colonial writers such as Anita Desai, Shashi Deshpande, Bharti Mukherjee, Kamala Dass, Kiran Desai, Manju Kapoor and Rupa Bajwa.

As a writer, Anita Desai exhibits a strong inclination towards the existentialist interpretation of the human predicament. In particular, she voices "the mute miseries and helplessness of married women tormented by existentialist problems and predicaments" [3]. Being a woman novelist, Desai has won a niche by exploring the emotional world of women, bringing to light the various deeper forces at work in feminine sensibility as well as psychology. This predilection leads her to examine the psyche of her women protagonists when they are confronted with the absurdity of life.

Quest for the definition of self and search for identity are the main features of the women of Bharti Mukherejee who are seen caught in the flux of conventional and contemporary.

Shashi Deshpande focuses on the working of psyche of her female characters. They desperately struggle to assert their individuality. Sensitive to the changing times and situations, they revolt against the traditions.

Namita Gokhale through her five novels depicts the struggle of women against the patriarchal norms that tries to suppress and extinguish her identity.

\section{REVIEW OF LITERATURE}

Ashok Kumar Novels of Manju Kapur 2010, Print [4].

Manju Kapur shot into fame with her debut novel Difficult Daughters (1998). A Married Woman (2002), Home (2005), and The Immigrant (2008), and Custody (2011), Kapoor's novels have a feministic approach. The present collection comprises of scholarly research papers and articles presenting an analysis of her novels as a struggle for emancipation from economic political and social bondages. But the present book does not explore the issues concerning the new woman.

Nadia Ahmed The Road to Baghdad, or Traveling Biculturalism: Theorizing a Bicultural Washington 2005. Print [5].

In this book, Nadia Ahmad discusses about tradition and modernity in the post-partition fiction of India. She observes that in Atta Hosain's Sunlight on a Broken Column (1961) and Manju Kapur's Difficult Daughters (1998) women protagonists suffer because of the partition and its aftermath. Binary opposition between tradition and modernity is a major force, two antagonistic poles obliterating the lives of the protagonists.

Letizia Alterno Post liberalization Indian Novels in English: Politics of Global Reception and Awards 2013. Print [6].

In this book, Alterno focuses on those Indian writers writing in the English language, whose concerns are related to India in her immediacy, and who have come attained literary fame in the post-liberalization period. Although the idea of this study is not to undermine the value of these writers, its aim is to consider the correlation of their novels' themes with the workings of the organized, global market processes now present in post-liberalized India. As per Alterno, Manju Kapur has based her novel Difficult Daughters on issues including impact of globalization, nationalism, Diaspora, identity crisis, communalism, subaltern representation and modernism

Elleke Boehmer "First realize your need: Manju Kapur's Erotic Nation" Alternative Indias: Cultural Diversity in Contemporary Literature in English, 2005. Print [7].

In this essay, the learned critic discusses the themes and motifs of Manju Kapur's novels. While her first novel Difficult Daughters is a family saga against the historical backdrop of partition, her second novel A Married Woman (2002) is a work of investigative reporting on the most controversial and political issue of the demolition of Babri Masjid and a woman's obsession with love and lesbianism. The novel is a kind of narrative on a woman's incompatible marriage and resultant frustration and the contemporary political turmoil in its historical context.

Urbashi Barat "From Victim to Non-Victim: Socialite Evenings as a Version of Kunstlerroman" The Fiction of Shobha De, 2000. Print [8].

In this book, Ms. Urbashi discusses how Shobha Dee is a trend setter. She becomes the symbol of highlighting different perspectives of woman's freedom and liberation. She conceives the extra-marital affairs of women as thse stroke to break the traditional and moral values in society. This is one of the most important aspects of her feminism.

It is concluded that all above mentioned critical books, research papers and articles do not address to the issue discussed in the paper. There is no elaborate work on the evolution and emergence of new woman in the post partition era. Hence the present study "Evolution of New Woman: A New Façade of Indian Culture in The Select Novels of Manju Kapur and Shobha De" will add a new milestone in the history of literary criticism. 


\section{NEW WOMAN IN INDIA: A CONCEPT AND REALITY}

The birth of "new woman" in India is a reality as the concept and position of womanhood has changed in the modern context. Attitudinal shift can be seen in the woman who longer shies away from taking the initiatives. Though this new change in thought has its variables, the results are relative depending upon the individual. This new woman is an assimilation of western influences as well as her native culture. She is a hybrid who despite of all kinds of upheavals, is able to strike a balance among diverse spheres of her life. The post-colonial modern novelists depict a "new woman" in their fiction, the woman who is the product of modern mercantile society, one who revolts against the traditional social set up. There is a consistent growth in her behavior and attitude. Thus, the journey of such woman becomes a case study of feminism.

The researcher here has explored the new women presented in the select novels of Manju Kapur and Shobha Dee. All domains of her growth, social, political and psychological remain the focus of our investigation. The new image of women presented by novelists under study is ambitious, lustful, power hungry and bold. They use sex as weapon to win and mould men to their viewpoint and get the better of them. This evolving new image of women has created a crisis in family and society and has shaken the foundations of age-old institutions like marriage and motherhood. Pre-marital sex, fornication, extra-marital relations or divorce are no longer considered to be a taboo. The concept of ideal Indian woman has become out-dated. A modern woman is career-oriented because she knows that it is her economic dependence which empowers a male to dominate his wife and subject her to physical and mental torture.

\section{A. Kapur's Prepetual Discourse on Education, Marriage and Polygamy}

Manju Kapur (1998-present), an internationally acclaimed Indian woman novelist has penned down five novels. She earned worldwide fame and recognition through her very first novel Difficult Daughters (1998). It also won her the Commonwealth Prize 1999 for first novels (Eurasia Section) and was a number one bestseller in India. Her second novel $A$ Married Woman (2003) was called 'fluent and witty' in the Independent, while her third, Home (2006) has been described as 'glistening with detail and emotional acuity' in the Sunday Times. The IMMIGRANT (2008) and CUSTODY (2011) are her most recent novels.

Manju Kapur takes into account the complexity of life, different histories, cultures and different structures of values in her plots. Her women under the patriarchal pressure and control are subjected to physical torture and social ostracism. They are more discriminated and are biased in lieu of their sex. But her heroines do not want to be rubber dolls in society rather they continuously strive to assert their identity. The key issues investigated by Kapur in her novels are education, marriage, and polygamy.

In Difficult Daughters, there are two kinds of women-traditional women like Kasturi, Ganga and Kishori Devi, the "New women" like Viramati, Shankutla, Swaranlata and Ida. The traditional women described in the book are covered by the clouds of ignorance, but the "New Women" are enlightened, they are constantly engaged in a battle against ideological imposition and power oppressions of patriarchal system but finally come out with what they claim to achieve. The novel centers on the complex mother-daughter relationship.

A Married Woman and Home deal with new women protagonists. They give us revolutionary themes, the plot centers on a woman's obsession with love and lesbianism. Here, 'new woman" is bold and modern in perspectives. She is job oriented, rebellious, educated and thoughtful.

Kapur's heroines are mostly educated, aspiring individuals caged within the confines of a conservative society. Their education leads them to independent thinking for which their family and society become intolerant of them. They struggle between tradition and modernity.

\section{B. Emergence of New Urban Woman in Shobha De'S Fiction}

Shobha De, (1989- present), a model cum journalist, is hailed as the ultra modern writer in Indian literary world. Apart from being the author of so many novels like Socialite Evenings (1989), Starry Nights (1991), Spouse: the truth about marriage,

Uncertain Liaisons (1993) and Strange Obsession (1992), she has also been the writer of many admired soaps on television, including India's second daily serial, Swabhimaan.

Shobha De depicts for the first time a new urban woman. Her novels and essays shatter patriarchal hegemony. People regard women inferior to men because of their different sex. She seems to be gifted with extraordinary ability to discuss very sensitive aspects of human life tactfully. In fact as a writer, she differs considerably from other Indian women novelists writing in English. She believes in very frank telling of incidents and absolute open-heartedness. We don't find anything reserved in her fiction from narrative point of view. The orthodox people in India criticize her for her open discussion on sexual matters. Despite of all criticism, her fiction has got tremendous response not only from several European countries but all over the world. It is no less an achievement.

Shobha De has become the symbol of highlighting different perspectives of woman's freedom and liberation. She conceives the extra-marital affairs of women as the stroke to break the traditional and moral values in society. This is one of the most important aspects of her feminism. Her women are daring and courageous in establishing extra-marital affairs to satisfy their natural urge. These women are not hesitant in using sex as calculated strategy to get social and financial benefit. Marriage for them is an insurance against social values.

Her novels can be thematically classified into three groups: firstly, Socialite Evenings and Second Thoughts are the novels that deal with the themes such as Family, Marriage, Patriarchy, quest for Identity, struggle for survival and marginality.

Secondly, Starry Nights, Sisters and Strange Obsession (1992) move around the life in film industry, Bollywood and concentrate basically on lust and sex. And finally, the novels 
Sultry Days (1994) and Snapshots (1995) present the emancipation of women and project the ultra-modern life style of neo-rich people

Shobha De's elite and educated women of the upper class family are trapped in the social institution of the marriage and family for the sake of money and honor as seen in "Socialite Evenings". As the story unfolds the life of these women, we find the sexual liberties of Anjali who at last seeks solace in religion after her second marriage with Kumar, an impotent and incompatible man; the gorgeous and vivacious Ritu who has developed flirting into a fine art and who leaves her second husband for a smuggler. Karuna's disappointment with her husband nourished her fantasy of a liberated woman.

De's Starry Nights is the story of the struggle and survival of a woman in a sex-starved society. It focused on women's struggle for recognition and survival and made them realize that the time has come when they should stop suffering silently in helplessness. She has marvelous understanding of the psyche of women. There are mainly three women characters, Geetha Devi, Malini, Aasha. All these women struggle for their inordinate ambitions with all their strength in male dominated society. In their efforts to assert themselves, sometimes they turn the applecart of patriarchal order upside down. They retaliate, revolt and shape their destiny by living for themselves. They "don't believe in suffering submissively, they leave no stone unturned to reach the peak of joy and success. Brimming with hope and zeal, they lay hands on hope in starry nights of their life. Their crusade against slavery, oppression and exploitation is alarming. " [9].

\section{REFERENCES}

[1] H. Stevens, Henry James and Sexuality, New Delhi: Cambridge University Press, pp. 27, 2008.

[2] J. Rosenberg, Flappers in the Roaring Twenties, London: Macmillan, pp. 25, 2004.

[3] V. V. N. R. Prasad, "Anita Desai and the wounded self," Indian Women Novelists, Ed. R. K. Dhawan, New Delhi: Prestige Books, Set. 1, vol. 11, 1991.

[4] A. Kumar, Novels of Manju Kapur, New Delhi: Sarup Book Publishers, 2010.

[5] N. Kumar, The Road to Baghdad, or Travelling Biculturalism: Theorizing a Bicultural Washington, Washington: New Academia, 2005.

[6] L. Alterno, Post liberalization Indian Novels in English: Politics of Global Reception and Awards, London: Anthem Press, 2013.

[7] E. Boehmer, "First realize your need: Manju kapur's erotic nation," Alternative Indias: Cultural Diversity in Contemporary Literature in English, Amsterdam: Rodopi, pp. 53-70, 2005.

[8] U. Barat, "From victim to non-victim: Socialite Evenings as a version of kunstlerroman," The Fiction of Shobha De, Ed. Jyadipshin Dodiya, New Delhi: Prestige Books, pp. 119-128, 2000.

[9] P. Syal, "Powder, puffs and Shobhaa De's fiction: The novel as consumer product," Contemporary Indian Women writers in English: A Feminist perspective, Ed. Surya Nath Pandey, New Delhi: Atlantic, pp. 53, 1999.

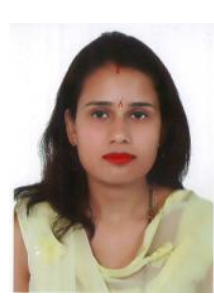

Priyanka Mahajan hails from the town Batala, the state of Punjab, India. She was born on 11 January 1982. She did her schooling from AVM. Senior Secondary School, Batala. Her academic and professional qualification are bachelors in commerce in 2001 from DAV College, Batala (affiliated to Guru Nanak Dev University, Punjab), MA in English Language and Literature in 2003 from BUC, College (affiliated to Guru Nanak Dev University, Punjab), Masters of Philosophy (English) in 2005 from Himachal University, Shimla and Qualified UGC-NET the eligibility test for permanent lectureship. She possesses 8 years of teaching experience as a lecturer in linguistics, English Literature and Business Communication. Presently, she is working as permanent assistant professor at State Technical University, Punjab, India. 